\title{
Pengaruh Inflasi Dan Pertumbuhan Ekonomi Terhadap Tingkat Pengangguran Di Indonesia Periode 2001-2017
}

\author{
Rts. Ivo Tri Aulia; Siti Hodijah; *Etik Umiyati
}

\author{
Prodi Ekonomi Pembangunan, Fak. Ekonomi dan Bisnis, Universitas Jambi
}

E-mail Korespondensi : umiyati.etik@yahoo.com

\begin{abstract}
The creation of jobs as a real impact of development policies that have been implemented in determining the success of economic development that occured in a country. The purpose of this study is to determine the effect of inflation and economic growth on the unemployment rate in Indonesia. The type of data used in this study is secondary data in the form 2001-2017 in Indonesia, with a method of multiple linear regression data analysis and analysis of development models. The results of the study with a significant level of $10 \%$ indicate that Simultaneously the variables of inflation and economic growth have a significant effect on the variable unemployment rate in Indonesia. In fact, economic growth variables have no significant effect on the unemployment rate while the inflation variable has a significant effect on the unemployment rate. $R$-square 0.280170 , this means that the unemployment rate in the period 2001-2017 in Indonesia is influenced by inflation and economic growth while the rest is explained by other factors not discussed in this model. The results of the analysis in development show that the inflation and economic growth variables experience fluctuating developments.
\end{abstract}

keywords: unemployment, inflation and economic growth

\begin{abstract}
Abstrak
Terciptanya lapangan pekerjaan sebagai dampak nyata dari kebijakan pembangunan yang telah dilaksanakan dalam menentukan keberhasilan Pembangunan ekonomi yang terjadi di suatu negara. Tujuan penelitian ini untuk mengetahui pengaruh inflasi dan pertumbuhan ekonomi terhadap tingkat pengangguran di Indonesia. Jenis data yang digunakan penelitian ini adalah data sekunder dalam bentuk runtun waktu (time series) dari tahun 2001-2017 di indonesia, dengan metode analisis data regresi linear berganda dan analisis model pengembangan. Hasil penelitian degan taraf signifikan $10 \%$ menunjukan bahwa Secara simultan variabel inflasi dan pertumbuhan ekonomi berpengaruh signifikan terhadap variabel tingkat pengangguran di indonesia. Secara persial variabel pertumbuhan ekonomi tidak berpengaruh signifikan terhadap tingkat pengangguran sedangkan variabel inflasi berpengaruh signifikan terhadap tingkat pengangguran. R-square 0.280170 , ini berarti tingkat pengangguran pada periode tahun 2001-2017 di indonesia di pengaruhi oleh inflasi dan pertumbuhan ekonomi sedangkan sisanya dijelaskan oleh faktor-faktor lain yang tidak dibahas di model ini. Hasil analisis dalam pengembangan menunjukkan bahwa variabel inflasi dan pertumbuhan ekonomi mengalami perkembangan yang fluktuatif.
\end{abstract}

Kata kunci: Tingkat pengangguran, inflasi dan pertumbuhan ekonomi 


\section{PENDAHULUAN}

Pengangguran merupakan suatu indikator penting dalam menganalisis pembangunan ekonomi. Masalah pengangguran yang lebih meningkat dalam pembangunan ekonomi merupakan masalah yang lebih rumit dan serius dari pada masalah perubahan dalam distribusi pendapatan yang kurang menguntungkan penduduk yang berpendapat rendah. Keadaan di Indonesia dalam beberapa tahun ini menunjukan bahwa pembangunan ekonomi yang telah tercipta tidak dapat mengadakan kesempatan kerja yang lebih banyak dan cepat dari pada pertambahan penduduk. Oleh karena itu masih banyaknya masyarakat yang menjadi pengangguran saat ini.

Dalam standar pengertian yang sudah ditentukan secara internasional, yang dimaksud pengangguran adalah seseorang yang sudah digolongkan dalam angkatan kerja, yang secara aktif sedang mencari pekerjaan pada suatu tingkat upah tertentu, tetapi tidak dapat memperoleh pekerjaan yang diinginkan.Pengangguran menunjukan sumber daya yang terbuang, para pengangguran memiliki potensi untuk memberikan kontribusi pada pendapatan nasional, tetapi mereka tidak dapat melakukannya.Pencarian pekerjaan yang cocok dengan keahlian mereka adalah menggembirakan jika pencarian itu berakhir, dan orang-orang yang menunggu pekerjaan di perusahaan yang membayar upah di atas keseimbangan merasa senang ketika lowongan terbuka.

Banyak faktor-faktor yang mempengaruhi pengangguran di Indonesia antara lain adalah inflasi dan pertumbuhan ekonomi. Faktor-faktor tersebut sangat mempengaruhi mengingat Indonesia adalah negara yang membutuhkan lapangan perkerjaan. Pertumbuhan ekonomi dan pengangguran sangat erat kaitannya apabila pertumbuhan ekonomi di indonesia mengalami peningkatan maka akan terjadinya kesempatan kerja bagi masyarakat di indonesia, karena pertumbuhan ekonomi merupakan suatu tolak ukur bagi keberhasilan pembangunan suatu negara. Sedangkan inflasi dan pengangguran adalah kedua jenis permasalahan serius yang harus segera ditangunggulangi oleh pemerintah. Inflasi dan Pengangguran merupakan masalah yang belum bisa teratasi dari zaman dahulu sampe sekarang. Jika diperhatikan masalah pengangguran dilingkungan sekitar bukan semakin berkurang melainkan semakin bertambah.

Pengangguran adalah masalah makroekonomi yang mempengaruhi manusia secara langsung dan merupakan yang paling berat.Bagi kebanyakan orang, kehilangan pekerjaan berarti penurunan standar kebanyakan orang, kehilangan pekerjaan berarti penurunan standar kehidupan dan tekanan psikologis. Jadi tidaklah mengejutkan jika pengangguran menjadi topic yang sering dibicarakan dalam perdebatan politik dan para polisi sering mengklaim bahwa kebijakan yang mereka tawarkan akan membantu menciptakan lapangan kerja (Arsyad, 2003). Tetapi secara aktif mencari pekerjaan tidak dapat digolongkan sebagai penganggur. Pengangguran adalah orang yang tidak bekerja sama sekali atau bekerja kurang dari dua hari selama seminggu sebelum pencacahan dan berusaha memperoleh pekerjaan. Selain itu pengangguran diartikan sebagai suatu keadaan dimana seseorang yang tergolong dalam angkatan kerja yang ingin mendapatkan pekerjaan tetapi belum memperolehnya (Sukirno,2000). Angkatan kerja meliputi populasi dewasa yang sedang bekerja atau sedang mencari kerja.Menurut 
Kuncoro (2000) Angkatan kerja terdiri dari golongan yang bekerja dan golongan yang menganggur.Golongan yang bekerja merupakan sebagian masyarakat yang sudah aktif dalam kegiatan yang menghasilkan barang dan jasa.Sedangkan sebagian masyarakat lainnya yang tergolong siap bekerja dan mencari pekerjaan termasuk dalam golongan menganggur. Golongan penduduk yang tergolong sebagai angkatan kerja adalah penduduk yang berumur 15 sampai 64 tahun (Sukirno,2000). Bukan angkatan kerja adalah bagian dari tenaga kerja yang tidak bekerja ataupun mencari pekerjaan, atau bisa dikatakan sebagai bagian dari tenaga kerja yang sesungguhnya tidak terlibat atau tidak berusaha terlibat dalam kegiatan produksi.kelompok angkatan kerja ini terdiri atas golongan yang bersekolah, golongan yang mengurus rumah tangga dan golongan lain yang menerima pendapatan.

Definisi singkat dari inflasi adalah kecenderungan dari harga - harga untuk menaik secara umum dan terus-menerus (Boediono, 2001). Kenaikan harga dari satu atau dua barang saja tidak disebut inflasi, kecuali bila kenaikan tersebut meluas kepada (mengakibatkan kenaikan) sebagian besar dari harga barang-barang lain.Inflasi terjadi jika proses kenaikan harga berlangsung secara terus-menerus dan saling mempengaruhi.

Pertumbuhan ekonomi adalah salah satu indikator penting penting untuk menganalisis pembangunan ekonomi yang terjadi di suatu Negara yang diukur dari perbedaan Produk Domestik Bruto (PDB) tahun tertentu dengan tahun sebelumnya. Perekonomian akan mengalami pertumbuhan apabila jumlah total output produksi barang dan penyediaan jasa tahun tertentu lebih besar dari pada tahun sebelumnya(Arsyad,2003). Pembangunan ekonomi merupakan suatu proses multidimensional yang meliputi perubahan dalam struktur sosial, perubahan dalam sikap hidup masyarakat dan perubahan dalam kelembagaan (institusi) nasional. Selain itu pembangunan juga meliputi perubahan dalam tingkat pertumbuhan ekonomi pengurangan ketimpangan pendapatan nasional dan pemberantasan pengangguran. Guna mencapai sasaran yang diinginkan dalam pembangunan, maka pembangunan suatu negara dapat diarahkan pada tiga hal pokok, yaitu meningkatkan ketersediaan dan distribusi kebutuhan pokok bagi masyarakat, meningkatkan kesejahteraan hidup masyarakat dan meningkatkan kemampuan masyarakat dalam mengakses baik kegiatan ekonomi dan kegiatan sosial kehidupannya.

\section{METODE}

Untuk menjawab tujuan pertama yaitu menggunaka analisis deskriptif, penelitian yang menggunakan analisis deskriptif dengan pendekatan kuantitatif bertujuan untuk menjelaskan dan menggambarkan variabel-variabel yang ada dalam penelitian, kemudian dipaparkan oleh penulis dalam bentuk angka-angka.

Dengan formula sebagai berikut (Gujarati,2006):

$\mathrm{G}=\frac{P_{n-P_{0}}}{P_{0}} \times 100$

Dimana :

$\mathrm{G}=$ Perkembangan inflasi, Pertumbuhan Ekonomi Dan Pengangguran 
$P_{n}=$ Perkembangan Inflasi, Pertumbuhan Ekonomi Dan Pengangguran Tahun Ke-n

$P_{0}=$ Perkembangan Inflasi, Pertumbuhan Ekonomi Dan Pengangguran Tahun Sebelumnya

Dan untuk perumusan masalah kedua yaitu Untuk mengetahui pengaruh inflasi terhadap pengangguran di Indonesia periode tahun 2001 - 2017.Digunakan rumusan sebagai berikut (Gujarati, 2006) :

$$
\mathrm{Y}_{\mathrm{t}}=\beta_{0}+\beta_{1} \mathrm{X}_{1 \mathrm{t}}+\beta_{2} \mathrm{X}_{2 \mathrm{t}}+\varepsilon
$$

Dimana:

$\begin{array}{ll}\mathrm{Y} & =\text { Pengangguran } \\ \mathrm{X}_{1} & =\text { Inflasi } \\ \mathrm{X}_{2} & =\text { Pertumbuhan Ekonomi } \\ \beta_{0} & =\text { Konstanta } \\ \beta_{1} \text { dan } \beta_{2} & =\text { Koefisien } \\ \varepsilon & =\text { eror term }\end{array}$

\section{HASIL DAN PEMBAHASAN}

Perkembangan Inflasi, Pertumbuhan Ekonomi Dan Pengangguran Di Indonesia

Untuk menjawab pertanyaan dari rumusan masalah yang pertama dalam penelitian ini, maka penulis mencoba menguraikan perkembangan dari masing-masing variabel dalam penelitian selama periode penelitian yakni dari tahun 2001 sampai dengan tahun 2017. Perkembangan masing-masing variabel yang akan diuraikan antara lain variabel tingkat pengangguran, inflasi dan pertumbuhan ekonomi di Indonesia periode tahun 2001-2017. Secara keseluruhan berkembang masing-masing variabel berfluktuasi setiap tahunnya dapat dilihat pada tabel berikut.

Tabel 1. Perkembangan inflasi, pertumbuhan ekonomi dan pengangguran di Indonesia

\begin{tabular}{cccc}
\hline Tahun & $\begin{array}{c}\text { Tingkat pengangguran } \\
(\mathbf{\%})\end{array}$ & $\begin{array}{c}\text { Inflasi (\%) } \\
\text { Pertumbuhan Ekonomi } \\
(\boldsymbol{\%})\end{array}$ \\
\hline 2001 & 8,10 & 12,55 & 3,32 \\
2002 & 9,06 & 10,03 & 3,7 \\
2003 & 9,67 & 5,06 & 4,1 \\
2004 & 9,86 & 6,40 & 5,1 \\
2005 & 11,24 & 17,11 & 5,7 \\
2006 & 10,28 & 6,60 & 5,48 \\
2007 & 9,11 & 6,59 & 6,3 \\
2008 & 8,39 & 11,06 & 6,2 \\
2009 & 7,87 & 2,78 & 4,5 \\
2010 & 7,14 & 6,96 & 6,1 \\
2011 & 7,48 & 3,79 & 6,5 \\
2012 & 6,13 & 4,30 & 6,23 \\
2013 & 6,17 & 8,36 & 5,56 \\
2014 & 5,94 & 8,36 & 5,01 \\
2015 & 6,18 & 3,35 & 4,88 \\
2016 & 5,61 & 3,02 & 5,02 \\
2017 & 5,50 & 3,61 & 5,07 \\
\hline Rata-rata & $\mathbf{7 , 8 6}$ & $\mathbf{7 , 0 5}$ & $\mathbf{5 , 2 2}$ \\
\hline
\end{tabular}

Sumber : Bank Indonesia, 2018 (diolah) 
Pengangguran menjadi salah satu penyakit dalam perekonomian, dimana masalah pengangguran bersifat kompleks dan multidimensial. Dari tabel perkembangan pengangguran yang terjadi di Indonesia dalam kurun waktu penelitian yang dilakukan selama periode 2001 sampai dengan 2017 diatas dapat dikatakan seperti tingkat perkembangan inflasi dan juga pertumbuhan ekonomi yang sudah dibahas diatas dapat dikatakan bahwa tingkat perkembangan pengangguran yang ada di Indonesia selama penelitian ini dalam keadaan yang berfluktuatif, dengan tingkat perkembangan pengangguran tertinggi terjadi pada tahun 2005 sebesar 11,24 \% tingkat pengangguran tertinggi ditahun ini terjadi tidak terlepas dari baru lepasnya negara Republik Indonesia dari krisis ekonomi yang melanda semenjak dari tahun 1997 dan juga bergantinya beberapa kali kepemimpinan negara, yang mengakibatkan banyaknya kebijakan pemerintah yang tidak berjalan dengan baik yang mengakibatkan berimbas kepada segala aspek terutama aspek ekonomi dan juga sosial, untuk perkembangan pengangguran yang terendah yang terjadi selama periode penelitian ini adalah pada tahun 2017 sebesar 5,50, rendahnya tingkat perkembangan pengangguran pada tahun ini lebih disebabkan kepada mulai membaiknya tingkat perekonomian negara Republik Indonesia yang berimbas kepada banyaknya tersedia lahan-lahan pekerjaan yang dapat dilakukan oleh masyarakat Indonesia. Secara rata-rata tingkat perkembangan pengangguran yang terjadi di negara Republik Indonesia selama penelitian ini adalah sebesar 7,86.

Dari data perkembangan inflasi pada tabel diatas dapat disimpulkan bahwa perkembangan inflasi yang terjadi di negara republik Indonesia yang terjadi selama periode penelitian yang dilakukan mengalami perkembangan yang berfluktuatif, dimana perkembangan inflasi yang tertinggi terjadi pada tahun 2005 sebesar 17,11\%, tingginya tingkat inflasi ini dikarenakan dampak dari kenaikan BBM yang terjadi pada saat itu, sedangkan untuk perkembangan inflasi yang terendah pada negara Republik Indonesia selama penelitian yang dilakukan terjadi pada tahun 2009 sebesar $(2,78 \%)$, rendahnya perkembangan inflasi pada tahun ini disebabkan kegiatan-kegiatan ekonomi yang dilakukan di negara Indonesia sudah mengalami kemajuan yang baik, terlebih pada saat itu pemerintah Indonesia dapat menghindari krisis ekonomi yang sudah terjadi pada negara-negara didunia terutama di benua Amerika dan Eropa, dalam penelitian ini juga didapati bahwa ada perkembangan inflasi yang berjalan dengan tidak mengalami kenaikan atau juga penurunan atau dalam keaadaan yang stagnan, perkembangan yang stagnan ini terjadi pada tahun 2014, dimana nilai inflasi pada tahun itu sebesar $8,36 \%$ sama dengan nilai inflasi tahun sebelumnya yang sebesar 8,36\%. Dari tabel diatas dapat dilihat bahwa rata-rata perkembangan nilai inflasi yang terjadi pada tahun penelitian yang dilakukan selama periode penelitian yang dilakukan dalam tahun 2001-2017adalah sebesar $7,05 \%$.

Dari tabel perkembangan ekonomi di negara Republik Indonesia selama periode penelitian yang dilakukan dari tahun 2001 sampai dengan 2017 didapati bahwa perkembangan pertumbuhan ekonomi di Indonesia mengalami perkembangan yang cukup berfluktuatif, dimana perkembangan tertingginya terjadi pada tahun 2011 sebesar $6,5 \%$ tingginya perkembangan pertumbuhan ekonomi yang terjadi di Indonesia pada 
tahun itu tidak terlepas terhadap adanya keuntungan dari krisis ekonomi yang dialami oleh negara-negara uni eropa. Krisis tersebut menyebabkan adanya perpindahan aliran dana ke emerging market seperti Indonesia.Sedangkan untuk perkembangan pertumbuhan ekonomi yang terendah selama periode penelitian ini terjadi pada tahun 2001 sebesar 3,32 persen, perkembangan terendah ini terjadi dikarenakan krisi global yang terjadi pada negara-negara uni eropa dan juga Amerika dan mempengaruhi keseluruh negara-negara yang ada didunia. Secara rata-rata perkembangan pertumbuhan ekonomi yang terjadi di Indonesia selama periode penelitian yang dilakukan mengalami perkembangan ekonomi sebesar 5,22\%.

\section{Hasil analisis regresi linear berganda}

Perhitungan data dalam penelitian ini menggunakan program pengolah data statistik yang membantu dalam pengujian model yang telah ditentukan. Selain itu perhitungan data juga bertujuan mencari nilai koefisien dari tiap-tiap variabel. Kemudian setelah melakukan olahan data maka didapat hasil berupa model persamaan regresi sebagai berikut.

$$
\begin{aligned}
& Y_{t}=\beta_{0}+\beta_{1} X_{1 t}+\beta_{2} X_{2 t} \\
& Y=6,422370+0,2423 X_{1 t}-0,053 X_{2 t}
\end{aligned}
$$

Dari persamaan regresi diatas terlihat nilai koefisien $\beta_{0}$ sebesar 6,422370 yang mana artinya, apabila selama periode penelitian ini variabel inflasi dan pertumbuhan ekonomi dianggap konstan atau tidak berubah, maka rata-rata tingkat pengangguran sebesar 6,422370 atau $6,4 \%$. Sedangkan koefisien regresi variabel inflasi $\beta_{1}$ diperoleh nilai sebesar 0,242372 artinya apabila terjadi kenaikan atau peningkatan inflasi sebesar 1 persen maka akan meningkatkan tingkat pengangguran sebesar 2,4\% persen, untuk regresi variabel pertumbuhan ekonomi $\beta_{2}$ diperoleh nilai sebesar $-0,050890$ angka ini dapat diinterpretasikan bahwa pengaruh variabel pertumbuhan ekonomi dalam negeri terhadap tingkat pengangguran yaitu jika, tingkat pengangguran dan inflasi di Indonesia tidak mengalami perubahan atau konstan selama periode 2001-2017, maka akan terjadi penurunan pertumbuhan ekonomi sebesar $1 \%$ pada setiap kenaikan $1 \%$.

Tabel 2. Hasil uji-t

\begin{tabular}{ccc}
\hline Variabel & t-Statistik & Prob. \\
\hline Inflasi & 2308611 & 0.0367 \\
Pertumbuhan ekonomi & -0.115995 & 0.9093 \\
\hline
\end{tabular}

Sumber : Data sekunder yang sudah diolah,2019

Dari tabel 5.5 di atas, dapat dilihat bahwa probabilitas inflasi lebih kecildari pada nilai $\alpha$ (0.10) atau $10 \%$ ini menunjukan bahwa variabel inflasi secara individu memiliki pengaruh yang signifikan terhadap variabel dependen yaitu tingkat pengangguran di Indonesia. Sedangkan pada variabel pertumbuhan ekonomi nilai probabilitasnya lebih besar dari pada nilai $\alpha(0.10)$ atau $10 \%$, ini menunjukan bahwa variabel pertumbuhan ekonomi tidak memiliki pengaruh signifikan terhadap tingkat pengangguran di Indonesia selama periode penelitian tahun 2001-2017. 


\section{Uji Multikolinearitas}

Uji Multikolinearitas dilakukan untuk menguji atau tidaknya hubungan linear yang sempurna atau pasti antara beberapa atau semua variabel yang menjelaskan model regresi. Jika nilai VIF lebij dari 10, berarti terjadi multikolinearitas dalam model regresi (Gujarati,2003).

Tabel 3. Hasil uji multikolinearitas

\begin{tabular}{cccc}
\hline Variabel & $\begin{array}{c}\text { Coefficient } \\
\text { Variance }\end{array}$ & $\begin{array}{c}\text { Uncentered } \\
\text { VIF }\end{array}$ & $\begin{array}{c}\text { Centered } \\
\text { VIF }\end{array}$ \\
\hline C & 6.288950 & 40.33441 & NA \\
INFLASI & 0.011022 & 4.528174 & 1.009831 \\
PERTUMBUHAN EKONOMI & 0.192517 & 34.67819 & 1.009831 \\
\hline
\end{tabular}

Sumber : Data sekunder yang telah di olah,2019

Dari hasil output, dapat dilihat nilai centered VIF lebih kecil dari 10 terdapat pada variabel inflasi dan pertumbuhan ekonomi sehingga dapat disimpulkan bahwa tidak terjadi multikolinearitas.

\section{Uji Heterokedastisitas}

Tabel 4. Hasil uji heterokedastisitas

\begin{tabular}{|c|c|c|c|}
\hline \multicolumn{4}{|c|}{ Heteroskedasticity Tes: Breusch-Pagan-Godfrey } \\
\hline F-statistic & 0.234857 & Prob. F $(2,14)$ & 0.7937 \\
\hline Obs*R-squared & 0.551851 & Prob. Chi-Square(2) & 0.7589 \\
\hline Scaled explained SS & 0.152561 & Prob.Chi-Square(2) & 0.9266 \\
\hline
\end{tabular}

Sumber : data sekunder yang telah diolah,2019

Penyakit atau masalah heteroskedastisitas umumnya hanya terjadi pada model yang menggunakan data observasi banyak objek atau cross section. Namun pada penelitian yang menggunakan data time series tetap harus dilakukan Uji Heterokedasitas, agar lebih menyakinkan pembaca terhadap hasil yang didapat dari penelitian ini. Pada hasil output diatas dapat dilihat nilai Chi Square hitung sebesar 0.551851 , yang dapat dilihat dari informasi Obs*R-squared. Sementara dapat dilihat nilai Prob. Chi-Square dari model sebesar 0.7589 atau $75.89 \%$ yang menunjukan bahwa nilai tersebut lebih besar dari nilai kritis Chi-Square yakni sebesar 0.10 atau $10 \%$. Dari analisis ini dapat disimpulkan bahwa tidak memilki sifat heterokedasitas.

\section{Uji Autokorelasi}

Tabel 5. Hasil uji autokorelasi

Breusch-Godfrey Serial Correlation LM Test:

\begin{tabular}{llll}
\hline F-statistic & 12.91080 & Prob. F(2,12) & 0.0010 \\
Obs*R-squared & 11.60626 & Prob. Chi-Square(2) & 0.0030 \\
\hline
\end{tabular}

Sumber: data sekunder yang sudah diolah,2019 
Hasil output diatas menunjukkan bahwa terjadinya autokorelasi. Hal tersebut dikarenakan nilai Prob Chi-Square lebih kecil 0.0030 atau lebih kecil dari nilai $\alpha=10 \%$ (0.10). Sehingga dapat disimpulkan bahwa terjadinya hubungan korelasi antar data tersebut atau data tersebut tidak saling berhubungan secara tidak langsung.

\section{Uji Normalitas}

Uji signifikansi pengaruh variabel independen terhadap variabel dependen melalui uji hanya akan valid jika residual yang didapatkan memiliki distribusi yang normal. Ada beberapa metode untuk mendeteksi apakah residual terdistribusi secara normal atau tidak, salah satunya yaitu melalui histogram dan uji yang dikembangkan oleh JarqueBera (JB) dalam ekonometrika.

Untuk mendeteksi apakah residual terdistribusi normal atau tidak, dapat dilihat pada nilai probabilitanya. Jika nilai probabilita $>\alpha 10 \% \quad(0.10)$ maka residual terdistribusi dengan normal.

\section{Gambar 6. Hasil Uji Normalitas}

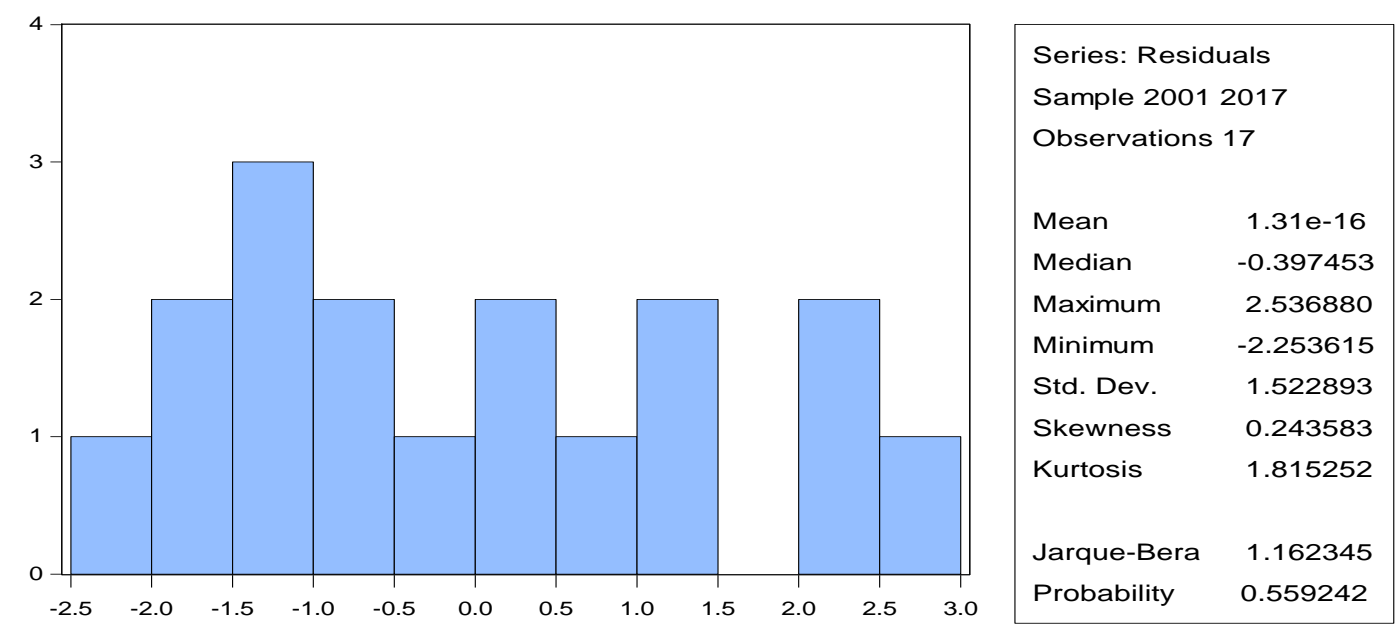

Sumber: data sekunder yang sudah diolah,2019

Karena nilai probabilita dalam uji tersebut sebesar 0.559242 atau $55.92 \%$ dan lebih besar dari nilai $\alpha$ maka dapat disimpulkan bahwa data terdistribusi dengan normal.

\section{KESIMPULAN DAN SARAN}

\section{Kesimpulan}

Dari hasil penelitian yang dilakukan terhadap inflasi dan pertumbuhan ekonomi terhadap tingkat pengangguran Di Indonesia pada periode penelitian 2001-2017 maka didapati kesimpulan untuk penelitian ini sebagai berikut :

Perkembangan variabel-variabel dalam penelitian ini berfluktuasi. Tingkat pengangguran dimana rata-rata perkembangan tingkat pengangguran ini sebesar $7.86 \%$ selama tahun 2001-2017. Inflasi dengan tingkat rata-rata perkembangan sebesar $7.05 \%$, dan pertumbuhan ekonomi dengan tingkat rata-rata perkembangan sebesar 5.22\%. 
Berdasarkan hasil regresi variabel inflasi memilki pengaruh yang signifikan terhadap tingkat pengangguran. Sedangkan variabel pertumbuhan ekonomi tidak terdapat signifikan terhadap tingkat pengangguran di Indonesia. Hal ini dilihat dari probabilitas pada $\alpha=(0,10)$ atau $10 \%$.

\section{Saran}

Penulis menyarankan pemerintah lebih memfokuskan bagaiamana cara untuk menekan inflasi yang terjadi di Indonesia, agar dapat menjadikan semua sektor yang ada dalam kegiatan ekonomi dapat berjalan lebih baik lagi.

Penulis menyarankan agar untuk mengurangi tingkat penganguran segala aspek yang berhubungan dengan pertumbuhan ekonomi dapat diberdayakan lebih baik lagi, berdasarkan hasil perhitungan regresi linier berganda yang dilakukan dalam penelitian ini, dapat dilihat bahwa pertumbuhan ekonomi cukup efektif dalam mengurangi tingkat pengangguran

\section{DAFTAR PUSTAKA}

Arsyad, Lincolin,(2001), Ekonomi Pembangunan, UPP YKPN, Yogyakarta , Edisi 3 (2003), Ekonomi Pembangunan, UPP YKPN, Yogyakarta

Badan Pusat Statistik (2008), "Indikator Ekonomi", Jakarta, BPS

Bank Indonesia (2017), "Buku Laporan Perekonomian Indonesia”, Jakarta, BI.

Boediono. "Ekonomi Makro, Seri Sinopsis Pengantar Ilmu Ekonomi no.1", Yogyakarta, BPFE, 2001.

Boediono. "Ekonomi Makro, Seri Sinopsis Pengantar Ilmu Ekonomi no.2", Yogyakarta, BPFE, 2001.

Gujarati, Damodar N, (2006). Ekonometrika Dasar, Jakarta: Penerbit Erlangga

Kuncoro, Mudrajad,(2000), Ekonomi Pembangunan, UPP YKPN, Yogyakarta.

Sukirno, Sadono.(2000) "Makroekonomi Modern", Jakarta : PT. Raja Grafindo Persada.

Sukirno, Sadono, (2000), Ekonomi Pembangunan, Penerbit Ghalia Indonesia, Jakarta , (2004), Ekonomi Makro, Penerbit Ghalia Indonesia, Jakarta 